\title{
A határon átívelő programok hatásai a Vajdaság területi fejlődésére
}

\section{The effects of cross-border cooperation programs on Vojvodina's regional development}

\author{
RICZ ANDRÁS
}

RICZ András: elnök, kutatási programvezető, Regionális Tudományi Társaság; 24000 Subotica, Matije Korvina 9., Szerbia; riczandras@rcgroup.co; https://orcid.org/00000001-9973-6015

KULCSSZAVAK: Vajdaság; határon átnyúló együttműködések; területi fejlődés

ABSZTRAKT: A Vajdaság - Szerbia korlátozott autonómiával rendelkező északi tartománya - számára az európai uniós határon átnyúló programok lehetőséget teremtettek a 2000-es évek elején, hogy fejlesztési forrásokhoz jusson, amelyeket a köz- és a civil szféra szereplői használhatnak fel. Munkám célja, hogy e források területfejlesztésre gyakorolt hatását vizsgáljam. Elemeztem a községek fejlettségének változása és a fejlesztések közötti összefüggéseket, az együttműködések hátterét és minőségét, jellegét a program hétéves periódusában. Összességében a Vajdaság területi fejlődésére az uniós források nem hatottak pozitívan, a területi fejlődés nem gyorsult fel, a területi egységek fejlettségi szintjei alig változtak a programok befejezésekor.

András RICZ: president, research program leader, Regional Science Association; Matije Korvina 9., 24000 Subotica, Serbia; riczandras@rcgroup.co; https://orcid.org/0000-0001-9973-6015

KEYWORDS: Vojvodina; cross-border cooperations; regional development

ABSTRACT: The cross-border EU programs becoming available in the early 2000s presented an opportunity to Vojvodina, a northern Serbian province with limited autonomy, to allocate development funds for its governmental and civilian sectors. The aim of my paper is to evaluate the impact of these funds on regional development, by analyzing development level changes of certain municipalities, the volume of allocated funds and their interrelations.

Vojvodina is bordering with three EU Member States (Croatia, Hungary and Romania), and Serbia has options for cross-border cooperation with all of them, financed by the European Union. The Croatian program is in its second budgetary period, while the two others are in their third cycles. In the article, as the starting point of the research, I outline the development levels in Vojvodina municipalities. Moreover, I show the background of these co-operations, their program features and their co-operation quality, and I also present them as projects impacting regional development. Based on statistical data, I compare their development level with respect to allocated funds in the 2010-2014 period. In the research I focused on only the ten most successful municipalities in implementing EU programs based on the data and analysis, and I

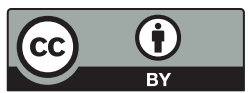


argue, that the cross-border cooperation programs of the European Union had no positive impact on the regional development in Vojvodina. We can say that the development path of the bigger towns was broken in 2012, while the smaller ones experienced a slight increase. Accordingly, we cannot conclude that cross-border cooperation funds have caused considerable development; however, these EU funds present statistically relevant development alternatives to smaller settlements. In general, the EU funds did not affect the regional development of Vojvodina positively: territorial development stagnated, and the development level of certain territorial units did not exceed levels from the period before. In overall, the evaluation of the period between 2009 and 2014 has shown that the projects were not be able to offset the external, primarily political and economic impacts that determined the development path of the area.

\section{Bevezetés}

Az Európai Unió IPA (Instrument for Pre-accession Assistance) alapának célja, hogy a csatlakozási folyamatban részt vevő országok felzárkóztatása felgyorsuljon. Szerbia szempontjából ennek az alapnak egyik prioritása az intézményépítés mellett a határon átnyúló programok támogatása volt a 2007-2013-as költségvetési periódusban. E programot megelőzte a Phare $C B C$, illetve az Interreg program, melyek keretében szintén lehetőség nyílt a határ menti fejlesztések uniós finanszírozására. Szerbia és ezen belül a korlátozott autonómiával rendelkező Vajdaság Autónom Tartomány speciális helyzetben van: a tartományt három oldalról határolják uniós tagországok, amelyek jelentős befolyást gyakorolnak fejlődésére.

Az Európai Unió célja egyértelmű Szerbiában: az integrációs folyamat folytatása, amely magában foglalja, hogy Szerbia közelítsen a szomszédos területek fejlettségéhez, erősítse a kapcsolatrendszert a tagjelölt és az uniós országok állami szervei és lakosai között, csökkenjen a határok elválasztó funkciója.

A fennálló helyzetben Szerbia célja sem lehet más, mint az integrációs folyamat felgyorsítása, annak érdekében, hogy minél előbb az unió teljes jogú tagjává váljon, és ne zárványként létezzen Kelet-Európa térképén. 2015-ben Szerbia megkapta a teljes jogú tagjelölti státuszt, valamint megkezdte a csatlakozási folyamatot, és a 2015-ös év folyamán négy megnyitott fejezettel elkezdte a csatlakozási tárgyalásokat. 2016 és 2017 folyamán további hat fejezetet nyitottak meg, melyekből kettőt ideiglenesen lezártak, így 8 tárgyalási fejezet vált nyitottá a 35-ből. Szerbia uniós csatlakozását az uniós és szerbiai szakértők is 2020 és 2022 közé prognosztizálják, amely számos tényezőtől - a csatlakozási tárgyalások gyorsaságától, bonyolultságától, Koszovó kérdésének megoldásától, illetve a világpolitikai folyamatoktól - is függ.

Munkám része egy átfogó vizsgálatnak, mely azt elemzi, hogy az előcsatlakozási alapok határon átívelő programjai segítették-e a Vajdaság területi fejlödését. Feltételezéseim szerint a Vajdaság területi fejlődésének kulcskérdése az uniós források hatékony lehívásában van, amely az integrációs folyamat során fog kiteljesedni. Az általam vizsgált 2007-2013-as uniós költségvetési periódus- 
ban megvalósított határon átnyúló projektek ennek csak egy - de az egész folyamatban jelentős szerepet játszó - szegmensét jelentik.

A feltételezésem megerősítése/elvetése érdekében bemutatom a 2014-es évvel záródó költségvetési periódusok határon átívelő programjait, illetve összehasonlítom a rendelkezésre álló községi szintű, fejlettséget bizonyító statisztikai adatsorokat a községek uniós forrásokat felhasználó (abszorpciós) képességével.

Határon átnyúló programok fejlesztésével, írásával és menedzselésével 2006 óta foglalkozom, és az elmúlt 10 év alatt több mint 25 projekt menedzselésében vettem részt. E projektek nagy része a magyar és a román határszakaszra vonatkozott, így rálátásom van a projektek végrehajtására, fenntarthatóságára és hosszú távú hatásaira. Mindhárom programterületen felhasználtam az elérhető statisztikákat, a hivatalos programértékeléseket, az elérhető tudományos és más publikációkat. Tanulmányomban röviden összefoglalom a téma irodalmát, elméleti hátterét, majd vázolom a Vajdaság határai mentén ez idáig lezajlott határon átnyúló programok eredményeit. Bemutatom a községek fejlettségi viszonyait és azokat az összefüggéseket, amelyek a községek fejlettsége és a külső forrásokat felszívó abszorpciós készsége között van.

\section{A határ, a határon átívelő együttmüködések és ezek hatásainak mérése}

A határmentiség, a határrégiók és a határon átnyúló együttműködések növekvő szerepét bizonyítja manapság a „bővülő Európában”, hogy jelenleg az EU területének közel felét a határrégiók vagy államhatárok által érintett térségek alkotják, a tagországok lakosságának pedig mintegy harmada él határrégiókban. Az Európai Unióban, mindenekelőtt a keleti bővítést követően meglehetősen általános sajátosság a határmentiség és a periferikus jelleg egybeesése (Baranyi 2014).

A határ funkcionálisan választ el eltérő politikai, intézményi rendszereket, s köt össze eltérő társadalmakat és közösségeket. Mindemellett a határokat permeabilitásuk, átjárhatóságuk szempontjából különböztethetjük meg. E funkciók jelenlétének eredményeként a határ lehet elválasztó (barrier), filter és híd vagy kapu szerepű (Kuttor, Ocskay 2015). A „nyitott” határ esetében a kontaktusfunkció a meghatározó.

Az államhatárok elvileg egy képzeletbeli vonalat jelentenek, bár a mai időkben egyre több esetben nemcsak képzeletbeli vonalként, hanem jól kiépített kerítésként (Kuttor, Ocskay 2015). Elméletben ez a vonal az, amely az államok területét egymástól elválasztja, ebből is látszik, hogy a határok az elválasztás és az összekötés ismérveit is magukon hordozzák (Rechnitzer 1999). A történelem folyamán egészen a rendszerváltás előtti időkig a határ politikailag meghúzott 
vonalat, katonailag szigorúan védett területet jelentett két ország között, amely kifejezésre juttatja azt, hogy a modern társadalmak empirikus létének kereteit az állam jelöli ki és tartja össze.

A politikai földrajz keretén belül az országhatárok térbeli vizsgálata a vonalelmélet és a zónaelmélet alapján végezhető el. Az országhatár vonalnak tekinthető jogi és földrajzi tekintetben, ugyanakkor tartalmi vonatkozásban zónának, térbeli kiterjedéssel rendelkező fogalomnak minősül. A határterület, ha két ország közötti határról van szó, a politikai földrajzban 20-50km széles sáv. Ez a sáv akár $100 \mathrm{~km}$ is lehet egy integráción belüli vizsgálódás esetében. A világrendszerek közötti határzóna mint pufferzóna pedig akár több ország területét is felölelheti. Mindezek alapján az országhatár mentén 20-50 km-es sáv között húzható meg a határtérség, attól függően, mi a vizsgálat célja (Böröcz 2002).

A határ menti kutatások egyik fontos kérdése a határ menti térség lehatárolása. E területet nem lehet egyértelműen 20-50 km-es határ menti zónának tekinteni, mert van, ahol keskenyebb és van, ahol szélesebb sáv ez a terület. Az a megoldás látszik kézenfekvőnek, ha a mutatók többségét szélesebb sávra, akár egy megye egész területére kidolgozzák és ezen eredmények alapján végzik el a pontos lehatárolást. Ha statisztikai-tervezési megközelítést alkalmazunk, akkor az uniós nómenklatúra szerint NUTS 3 területi egységeket sorolhatunk a határ menti térségek közé. Fontos szempont, hogy az uniós programok ezeket a területi egységeket használják a határ menti fejlesztési programok tervezése és végrehajtása során (Hardi, Hajdú, Mezei 2009).

A területi jelenségek, folyamatok összetettsége miatt szinte sohasem lehetséges, hogy az előfordulást, a térbeli elosztást egyértelműen meg lehessen határozni. A valós határok megvonása, lehatárolása nehéz feladat, ugyanis a határok elmosódottan jelennek meg és átmenetekből állnak. E tényből adódóan a kijelölt határ, amely egy kutatás alapját képezi, pontatlan lehet. Példaként említhető, hogy a területi kiegyenlítődésre vonatkozó számítások egymással ellentétes következtetéseket adtak eredményül akkor, amikor a különböző területi egységek alapján végezték el a számításokat. Emiatt célravezető a területi elterjedések térbeli vizsgálatánál, ha az több lépcsőben, fokozatosan, területi hipotézisek alapján történik.

A határon átnyúló kapcsolatokon azokat a jelenségeket értjük, amelyek magában a határtérségben történnek, és a határokon keresztül a térségben élők mindennapjait alakítják. Ezek az interakciók kapcsolatban lehetnek a munkavállalással, a lakóhelyválasztással, a szolgáltatások igénybevételével, de a közigazgatási ügyek intézésével is. A határok nyitottsága befolyásolja ezeket a jelenségeket, de alapjában véve az interakciók mennyiségi és tematikus sűrűsége a meghatározó.

A határ menti együttműködés egyidős a határok kialakulásával. Magyarország esetében a trianoni határmódosítás után a kapcsolatok tovább éltek Ausztriával és Jugoszláviával is egészen a második világháború kezdetéig. Fennmaradt például a kettős birtokossági rendszer. A második világháború után, de főleg az 
ötvenes években a kommunista vezetés lezárta a határokat. Ez a hermetikus lezárás csak a hatvanas években enyhült, folyamatosan egészen a rendszerváltásig, amikor is megnyíltak a határok (Hardi 2010).

Az, hogy egy adott terület az államhatár mellett fekszik, önmagában nem jelent szükségszerűen hátrányt a társadalmi-gazdasági fejlődésre, sőt, bizonyos esetekben kifejezetten előnyös is lehet. Trianon óta Magyarországon a határmentiség - kivéve talán a nyugati határszélet - általában elmaradottságot jelentett. Elsősorban azért, mert ezek a határ menti területek kevésbé integrálódtak az ország gazdasági vérkeringésébe, aminek számos, de elsősorban politikai oka volt. Másrészt, a határ mentének az elmúlt közel száz évben alig volt kapcsolata a határon túli - valamikor egy országhoz tartozó - szomszédos régióval.

Nyugat-Európa több országában alkalmaztak kedvezményeket a nemzetiségek lakta, gyengén fejlett térségek gazdasági felzárkóztatásában, juttattak pótlólagos forrásokat a kultúra és az oktatás támogatására (Horváth 2015). Ezzel szemben Kelet-Európában ellentétes folyamatoknak voltunk-vagyunk szemtanúi. Negatív diszkrimináció jellemzi a határ menti területek fejlesztését, Szerbiában is. A határok a nemzetpolitikában jelentős szerepet játszanak, kiemelten Magyarországon, ahol a szomszédos ország határterületein jelentős magyar kisebbség él.

A Vajdaságban mindhárom országhatár mentén lehetőség lenne a jelenleginél is mélyebb kapcsolatok kialakítására, érvényesítve a komparatív előnyöket, megszüntetve a párhuzamos fejlesztéseket. Az erőforrások jobb kihasználásával gyorsabb fejlődési pályára állhatnának a közös határral elválasztott régiók is.

Már a Római szerződésben is megjelenik a gazdasági tényezők szabad áramlásának és a kiegyensúlyozott területi fejlődésnek az igénye, de a határ akkor még elválasztó vonalként manifesztálódott. Harminc évnek kellett eltelnie, hogy az uniós politikák jelentős beavatkozásai eredményt érjenek el. Mindezek mellett a határtérségben lévő települések, városok hátrányos helyzetben voltak addig is a földrajzi elhelyezkedésük miatt. Ezt kompenzálva próbáltak kapcsolatokat kiépíteni a szomszédjaikkal, ami sok esetben jelentős kihívást jelentett (Pete 2014).

Nyugat-Európára a periferiális jelleg kevésbé jellemző, a határtérségek lemaradása kisebb, mint Kelet-Európában, ahol a perifériák perifériái találkoznak sok esetben egymással a határ két oldalán. A Vajdaság szempontjából, melyet négy ország is határol, a határkérdések megkülönböztetett figyelemmel bírnak minden szempontból. A tartomány szemszögéből a határmentiség és a periferiális jelleg a folyamatos leépülés eredménye, ami az elmúlt 100 év jugoszláv, majd szerb politikájának tulajdonítható. Az uniós források a határ menti periferiális térségek felzárkóztatásában játszhatnak jelentős szerepet, amennyiben sikerül e projekteket megfelelő módon megvalósítani, a forrásokat a hosszú távú célok érdekében felhasználni.

A határon átnyúló kapcsolatok célterületei a vállalkozások (Baranyi 2001), a vállalkozók és a gazdasági kamarák, illetve e szereplők együttműködésének erősítése. A gazdaságfejlesztésben, mint a területfejlesztés egy eszközében, így 
jelentős szerepet játszanak a határon átívelő programok, főként, ha a meglévő kapcsolatrendszerek és az erre épülő együttműködések fejlesztését tűzik ki célul uniós források felhasználásával. A határrégiók akár a további európai uniós integráció előmozdításának motorjai lehetnek (Szabó 2005). A régiók közötti eredményes együttműködés feltételei között legfontosabb az infrastruktúra fejlesztése, amely a telekommunikáció terén ma már jórészt megvalósult. Annál nagyobb akadály a közutak, vasutak, határátkelőhelyek állapota, száma, a közlekedési eszközök, járatok sűrűsége. A külső európai határokon a határátkelők száma és kapacitása a kapcsolatépítést leginkább hátráltató tényező. A gazdasági együttmúködést is jellemzően az elmaradott infrastruktúra, illetve a jogi akadályok befolyásolják kedvezőtlenül, elsősorban a külső határok mentén.

Az Európai Unió külső határait körülvevő nem tagállamok, amelyek egy része potenciális tagjelölt, balkáni államok sajátos csoportja. Esetükben külön európai előcsatlakozási források támogatják a határ menti együttműködéseket (jelenleg az IPA, a CBC, az SEE, míg korábban az Interreg IIIA és a CADSES). Ezek a központi támogatási eszközök igen hasznosak lehetnek az érintett területek felzárkóztatásában, ugyanakkor nem elégségesek, mivel elsődleges céljuk a határtérségben élők kapcsolatrendszerének növelése, és csak másodlagos cél a leszakadó térségek fejlesztése. A helyi fejlesztési szakemberek szerint a szerb-magyar határ menti térség, más prosperáló európai határ menti övezethez hasonlóan, alkalmas lehetne a jól működő területfejlesztési együttműködés megteremtésére (Kovács 2012).

A területfejlesztési támogatások hatáselemzése előtt álló legnagyobb kihívás a megfelelő teljesítményindikátor létrehozása. Mivel a programok sokszínűek, emellett jellemző rájuk a komplexitás is, nem elég egy-egy statisztikai mérőszám a területi fejlődés mérésére, hanem több jellemző adatsort kell figyelembe venni (Ferto", Varga 2015).

\section{A Vajdaság területén lezajlott uniós támogatási programok rövid összefoglalása}

A Vajdaság valamikor Jugoszlávia egyik legfejlettebb térsége volt (Horváth, Hajdú 2010; Petak 2005), majd az ország szétesésével Szerbia vezető gazdasági területe lett. Mára viszont elvesztette ezt a pozícióját, a belgrádi régió már minden gazdasági mutatóban fejlettebbnek számít, mint ez a - valamikor jelentős mezőgazdasággal és élelmiszeriparral, valamint feldolgozóiparral rendelkező - tartomány.

Az elmúlt tíz évben folyamatosan nyíltak meg uniós támogatási források, amelyeket elsősorban az állami struktúrák, az önkormányzatok, állami és önkormányzati alapítású intézmények és kisebb mértékben civil szervezetek használtak fel. 
Az Európai Unió által megnyitott támogatási programok közül a határon átívelő programok voltak legelőször elérhetőek, amelyekre a 2000. évi szerbiai rendszerváltás után lehetett pályázni. Az Európai Unió a 2003-as programozási évben nyújtott először lehetőséget a tartomány számára, hogy a Phare (Poland and Hungary: Assistance for Restructuring their Economies) CBC (Cross Border Cooperation) program keretében fejlesztési forrásokat hívjon le szomszédsági programok keretében. Majd pedig 2006-tól az Interreg programok segítségével további felzárkóztató támogatásokhoz jutottak a tartomány önkormányzatai, intézményei és civil szervezetei a Magyarországgal és Romániával közösen kiírt pályázatokon (Ricz 2012).

A határ menti szerep, amely a Vajdaság községeinek hozzávetőlegesen 40\%-ánál közvetlenül megjelenik, jelentős mértékben predesztinálja a területi fejlődést. Elsősorban azért, mert a szerb terület- és regionális fejlesztési stratégiák csak nagyon korlátozottan foglalkoznak a periferikus területekkel (Strategija regionalnog razvoja republike Srbije za period od 2007 do 2012 godine). Mindez igaz a Vajdaság esetében is, hiszen a regionális fejlesztési terv akciótervében egyáltalán nincs szó a Vajdaságról. Másodsorban a lakosság nemzeti összetétele (a nemzeti kisebbségek erőteljes jelenléte) sem serkenti a hivatalos politikát a térség fejlesztésére. A határon túli kapcsolatrendszerrel rendelkező önkormányzatok és más potenciális pályázók ezt felismerték, és már az első pályázati kiírásoktól kihasználták az uniós források adta lehetőségeket.

Fejlesztési szempontból a határ menti szerep kettős: egyrészt hátrányt okoz a hazai forrásokból finanszírozott fejlesztések elmaradása miatt, másrészt viszont lehetőséget ad az uniós források lehívására, amelyek célja a területi különbségek csökkentése. Jól bizonyítja ez azt is, hogy amit az adott állam fejlesztéspolitikája nem tud vagy nem akar megoldani, azt megteszi egy nyitottabb, haladóbb gondolkodású, demokratikusabb közösség, az Európai Unió, ezen az úton is építve az egységes Európát.

A 2007-2013-as uniós költségvetési periódus idején, az IPA határon átnyúló programjainak keretében vizsgált három programterületen (szerb-magyar, szerb-román és szerb-horvát) összesen nyolc pályázati kírásra került sor. Szerb-magyar viszonylatban három alkalommal volt lehetőségük a pályázóknak projektterveket beadni, 2009-ben, 2011-ben, és 2012-ben. Az 1. prioritás az „infrastruktúra és környezet” nevet viselte, mely további két alprioritásra oszlott: infrastruktúra-fejlesztésre, melynek keretében a határon átnyúló, településeket összekötő útszakaszok építését, felújítását, valamint a határon átnyúló közlekedési útvonalak tervezését, a közösségi közlekedés összehangolását támogatták közös projektekben. A második alprioritás a „közös felelősségvállalás a környezetért" elnevezéssel kisebb léptékű vízgazdálkodási (ár- és belvízvédelem) tevékenységeket, valamint állategészségügyi monitoringot és a környezet minőségét javító tevékenységeket finanszírozott.

A 2. prioritás „gazdaság, oktatás és kultúra” elnevezéssel szintén két alprioritást foglalt magába. A gazdasági együttműködés, turizmus és kutatás-fejlesz- 
tés keretében képzéseket és határon átnyúló üzleti partnerkeresést, határon átnyúló kulturális útvonalak létrehozását, kulturális örökségvédelmet, a régió terület- és ágazati fejlesztéséről szóló közös tanulmányok kidolgozását, valamint termékorientált közös kutatás-fejlesztést és innovációt célul kitűző projektet támogatott az Európai Unió.

Az oktatási és kulturális együttműködések alprioritásban oktatási együttműködéseket és emberek közötti együttműködéseket támogattak.

A 3. prioritás a „technikai segítségnyújtás” volt. A program indikatív pénzügyi terve közel 34 millió euró uniós finanszírozással számolt, amelyhez 6 millió euró társfinanszírozás társult, így összesen a tervezett program költségvetése megközelítette a 40 millió eurót. Az első prioritásra a tervezett összeg 52\%-át szánták, a második prioritásra 38\%-át, a technikai segítségnyújtásra pedig 10\%át (Lazarević, Knežević, Božić 2011).

A három kiírásban több mint 750 projektterv érkezett be, amelyből az első körben 70, a második körben 67 pályázóval kötöttek támogatási szerződést, míg a harmadik körben 61 projektet választottak ki. A fennmaradt támogatási összeget a harmadik kör tartaléklistájára került projektjei között osztották szét (Prime Minister's Office 2015).

A román-szerb viszonylatban a két kiírás során mintegy ötszáz pályázatot adtak be, a két körben összesen 61 támogatási szerződést kötöttek meg. A program 3 prioritásból állt, amelyek további intézkedésekre oszlottak. A prioritások közül az első a gazdasági és társadalmi fejlődés elősegítése volt, mely magában foglalta a lokális és regionális üzleti és szociális infrastruktúra fejlesztését, a turisztikai szektor fejlesztését, kiemelve a határrégiót, ahol a turisztikai desztináció fejlesztését, a kis- és középvállalati szektor fejlesztésének elősegítését, valamint a kutatás-fejlesztés és az innováció elősegítését tűzték ki célul. A második prioritás a környezetvédelem és az árvízi felkészültség növelése volt a határ menti környezetvédelmi problémákra adott válaszokkal, az árvizek elleni felkészülést elősegítő stratégiák kidolgozására és fejlesztésére, továbbá a környezeti veszélyekre figyelmeztető rendszerek kidolgozására vonatkozó projektek támogatásával. A harmadik prioritás az emberek közötti kapcsolatok fejlesztését tűzte ki célul, amely magában foglalta a civil szervezetek és a helyi közösségek közötti kapcsolatok fejlesztését, a helyi önkormányzatok humán szolgáltatásainak minőségi javítását, oktatási, kulturális és sportcsereprogramok finanszírozását, valamint a határrégió szociális és kulturális integrációját.

A program indikatív költségvetése 23 millió euró volt, amelyből az Európai Unió támogatása közel 20 millió euró, a társfinanszírozás pedig 3,5 millió euró volt. Az első prioritásra a költségvetés $50 \%$-át, a másodikra $26 \%$-át, a harmadikra 14\%-át, a technikai segítségnyújtásra pedig 10\%-át tervezték (Romania-Serbia IPA Cross-Border Cooperation Programme Programming Document 2008).

A horvát-szerb viszonylatban a háborús időszakot követően hirdettek meg először együttműködési programot: kísérleti projektként a 2010-es első körben összesen 2,7 millió euróval támogattak 11 pályázatot, a 2012-ben meghirdetett 
második körben pedig 5,6 millió euró forrás felhasználásával szintén 11 határ menti projekt megvalósítására került sor. 2015 májusában még egy harmadik pályázati kiírás is volt, e projektek végrehajtása még nem fejeződött be (Pejović et al. 2014). A program két prioritásból állt: az első a fenntartható társadalmi és gazdasági fejlődés, a második pedig a technikai segítségnyújtás, vagyis a program megvalósítása. A fenntartható társadalmi és gazdasági fejlődés prioritásnak három intézkedése volt: a gazdasági fejlődés, a környezetvédelem és az emberek közötti programok (Instrument pretpristupne pomoći (IPA) Prekogranični program Hrvatska-Srbija 2007-2013).

Ismerve a jogszabályi és tervezéspolitikai hátteret, bátran ki lehet jelenteni, hogy ezek a támogatások jelen pillanatban az egyedüliek, amelyek jelentős külső fejlesztési forrásokat vonnak be a Vajdaság területi fejlesztésébe (Program razvoja Ap Vojvodine 2014-2020). Az infrastrukturális projektek végrehajtásával olyan fejlesztések valósulhattak meg, amelyeket az ország a saját erejéből csak nagyon sok év múlva tudott volna megoldani, elsősorban a periferikus jelleg miatt.

Ha összességében vizsgáljuk mindhárom határszakasz projekteit, megállapítható, hogy a határátkelők, a határokra vezető utak, a határ menti utak, a kerékpárutak tervezése és építése, a vasutak tervezése, a vízügyi beruházások mind olyan tevékenységek, amelyek elsősorban a határ szerbiai oldalán élők számára teszik könnyebbé a mindennapi életet, illetve további fejlesztéseket indukálnak. A jó megközelíthetőség, a turisztikai attrakcióként használható kerékpárutak tökebefektetéseket vonzanak a térségbe, új vállalkozások indulnak, új munkahelyek jönnek létre, ami a helyi lakosság számára életszínvonal-emelkedést jelent.

A vízügyi beruházásokat két részre lehet osztani: az egyik az árvizek és belvizek elleni védekezés, amely több esetben jelenti a fizikai védelmi rendszerek kiépítését, ezzel növelve az adott térség, valamint a lakosság biztonságát. A másik projektcsoport a tiszta és biztonságos ivóvízzel való ellátást segíti a térségben. Ezek a fejlesztések a jövőbeni fejlődést hordozzák magukban, mivel a lakosság számára olyan kockázati forrásokat csökkentenek, amelyek évszázadok óta fennállnak.

A határ menti fejlesztési terveket előkészítő projektek talán még nagyobb jelentőségűek, mint az infrastrukturális fejlesztések. A tervezés során olyan dokumentumokat gyűjtöttek össze, melyeket a közeljövőben lehet majd felhasználni új uniós források lekötésére.

A programok által támogatott pályázatok közül csak azokat vizsgáltam, amelyek valamilyen módon a területfejlesztéssel vannak kapcsolatban, tehát az infrastrukturális, gazdasági-turisztikai, innovációs és környezetvédelmi nyertes és megvalósított pályázatokkal foglalkoztam. A gazdasági fejlődést elősegíto projektek elsődleges eredménye, hogy a vajdasági vállalkozások megismerték az uniós szabályozási, támogatási gyakorlatot, a specifikus müködési környezetet, és új kapcsolatokat építettek ki a szomszéd országokkal, amelyekkel a jövo"ben együttműködve képesek lesznek működőtőke-beruházásokat a térségbe vonzani, ezzel is növelve a régió által kibocsátott összterméket. 
A három határszakasz projektjeinek mélyfúrásszerü elemzése módot adott a magyar, a horvát és a román határszakasz lehetőségeinek, teljesítményének és jövőbeni megoldásaiknak összehasonlítására (Nezavisno Društvo Novinara Vojvodine 2015). Minden esetben a helyi kezdeményezések és a meglevő lehetőségek kihasználásáról van szó, alulról jövő kezdeményezésként, de azt sem szabad figyelmen kívül hagyni, hogy több esetben magyar-magyar kapcsolatról beszélhetünk, tehát a három országban élő magyar nemzetiségü emberek közötti együttműködésről, ami a határ menti programok indukálója lehet (Ricz 2016). A két nagyobb program (magyar és román) területileg jól kiegészíti egymást, mivel a magyar-szerb programterület nyertes projektjei jellemzően az északi határ menti sávot fedik le, a román projektek pedig a Tisza mentét és a Bánságot, ezek mellett a horvát program - területét és költségvetését figyelembe véve - csak kiegészítő lehet. Minden programban fellelhető a humánerőforrás-fejlesztés, amely a helyi kezdeményezések számára elsődleges, hiszen így tudnak egy fenntartható és önműködő rendszert kialakítani a későbbi források bevonásához, és így idővel remélhetően nem kell majd külső segítséget bevonni.

A projektek vizsgálatát summázva (Nađ et al. 2015) megállapítható, hogy azok sok esetben összefogást eredményeztek, és megalapozták a helyi közösségeken belül azokat a lehetőségeket, amelyeket kihasználva további fejlesztési források hívhatók le. A határ menti projektek célja a határon átívelő kapcsolatok erősítése és a periferikus területek fejlesztése. Szerbia számára megalapozzák a későbbiekben elérhetővé váló előcsatlakozási alapok támogatásának minél nagyobb lekötését, amiből a vajdasági magyarság is profitálhat, ha élni tud a felkínált lehetőségekkel (Ricz 2015).

Összefoglalva, a határ menti uniós finanszírozású programok jelentős hatással voltak azokra a pályázó szervezetekre, amelyek élni tudtak a lehetőséggel (sajnos ez kevés szervezetre volt jellemző). A projektek olyan fejlesztéseket eredményeztek, amelyek segítették a szervezetek kitörését a periferikus helyzetből. A projektek sikeres végrehajtása megmutatta, hogy melyek az életképes közösségek és a jó projektötletek, ezeket a későbbiekben tovább lehet fejleszteni. A megvalósított fejlesztések jó példával szolgáltak mások számára: el lehetett érni uniós forrásokat a Vajdaság fejlesztésére. A határon átívelő programok viszonylag kockázatmentes felkészülési lehetőséget nyújtottak a jövőbeni uniós források fogadására, kialakult egy tapasztalattal rendelkező szakmai réteg, amely a későbbiekben is végre tudja hajtani a jelentkező projektfeladatokat (Ricz 2012).

\section{A községek fejlettsége a Vajdaságban}

Ahhoz, hogy ki tudjuk mutatni a Vajdaságban az uniós programok hatását a területi fejlődésre, ismerni kell a társadalmi, gazdasági politikai viszonyrendszereket és az ezek összefüggéseinek eredményeként megvalósuló fejlődési folyamatokat. 
Szerbia NUTS régióinak kialakítása hosszas vita után valósult meg. A jelenleg hatályos regionális fejlesztési törvény és a statisztikai területi egységek nómenklatúráját meghatározó kormányrendelet értelmében a Szerb Köztársaság két NUTS 1 régióra tagolódik: Észak-Szerbiára és Dél-Szerbiára. Észak-Szerbiát két NUTS 2 régió alkotja: a Vajdaság régió és a Belgrád régió, míg Dél-Szerbia szintén két NUTS 2 régióra tagolódik: Sumádia és Nyugat-Szerbia, valamint Délés Kelet-Szerbia régiókra. A törvény szerint Koszovó és Metóhia szintén NUTS 2 régióként szerepel, figyelmen kívül hagyva ezáltal Koszovó 2008 elején egyoldalúan kikiáltott függetlenségét. A Szerb Köztársaság területén 30 NUTS 3 régiót határoltak le (körzetek/térségek) (Uredba o nomenklaturi statističkih teritorijalnih jedinica).

A körzetek/térségek funkcionális területi egységek, a tervezés és regionális fejlesztéspolitika végrehajtásának hordozói (Tripković 2003). A NUTS 3 régiónál alacsonyabb szintek a LAU 1 (községek ${ }^{1}$ ) és a LAU 2 (települési szint) (1. ábra).

1. ábra: Szerbia statisztikai tervezési régiói Statistical planning regions in Serbia

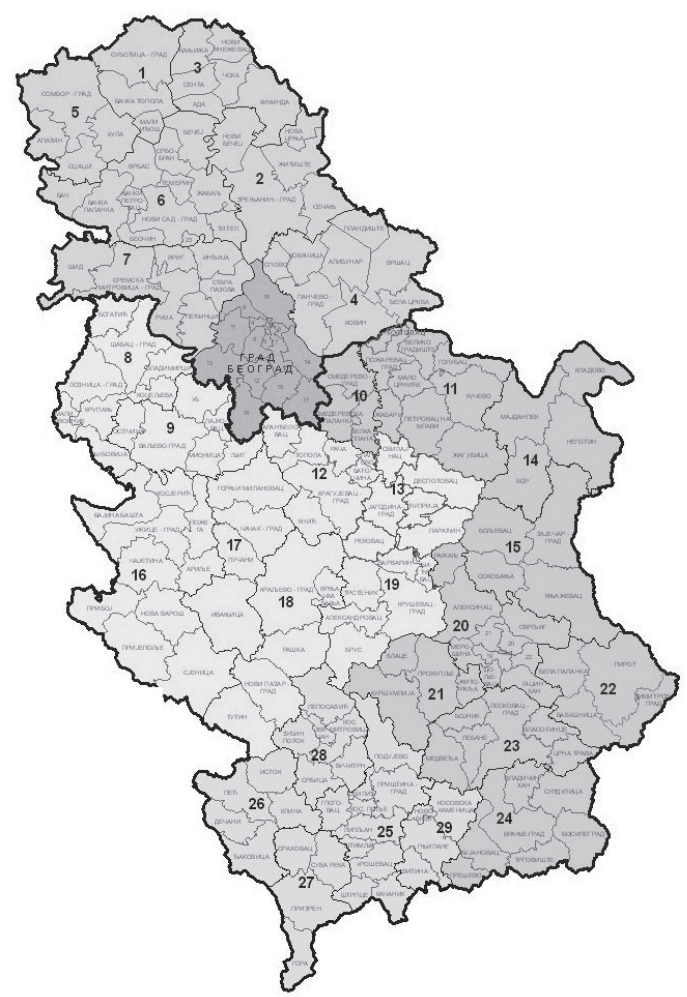

Jelmagyarázat: 1-7: Vajdaság; 8-19: Sumádia és Nyugat-Szerbia; 10-24: Dél-és Kelet-Szerbia; 25-29: Koszovó; számozás nélkül: Belgrád.

Forrás: Saját szerkesztés Republički Zavod za Statistiku (2011-2015) alapján. 
A községek fejlettségi szintjét évente alapmutatók (a jövedelmek és nyugdíjak összessége az adott önkormányzat területén; a költségvetési jövedelem, kivéve a más kormányzati szervektől származó költségvetési bevétel összegét) és korrekciós mutatók (demográfiai növekedés vagy csökkenés; munkanélküliségi ráta, a lakosság iskolai végzettsége) alapján Szerbia Kormánya kormányrendelettel határozta meg 2014-ig. 2014-óta nem határozták meg a községek fejlettségi szintjét, azóta minden állami szerv ezt az utolsó, hivatalos fejlettséget mutató rangsort használja (Uredba o utvrdjivanju metodologije za izračunavanje stepena razvijenosti regiona i jedinica lokalne samouprave). A községeket fejlettségük szerint öt csoportba sorolhatjuk:

- 1. csoport: önkormányzatok, melyek fejlettségi szintje meghaladja a köztársasági átlagot,

- 2. csoport: önkormányzatok, melyek fejlettségi szintje a köztársasági átlag 80-100\%-a,

- 3. csoport: önkormányzatok, melyek fejlettségi szintje a köztársasági átlag 60-80\%-a,

- 4. csoport: önkormányzatok, melyek fejlettségi szintje a köztársasági átlag 50-60\%-a,

- 5. csoport: önkormányzatok, melyek fejlettségi szintje a köztársasági átlag 50\%-a alatti.

Fejletlen községek fóként a déli területeken és a keleti határ mentén találhatók, de egyre több fejletlen község van a Vajdaság déli, délkeleti részén is. A szegénység mértékében szintén extrém eltérés tapasztalható a fejlett és a fejletlen régiók között: a fejlett területeken a szegényeknek csupán 8,5\%-a él, míg 18,7\%-uk található a fejletlen rurális területeken.

A községek fejlettségi mutatói a kutatómunkám fó alapadatai, mivel Szerbiában jelenleg csak ezek a mutatók állnak a kutatók rendelkezésére. Célom annak vizsgálata, hogy a határon átívelő projektek által felhasznált fejlesztési források milyen területfejlesztési eredményeket hoztak, hogyan alakultak a községek (LAU 1) közötti fejlődésbeli különbségek elsősorban az elmaradott vagy leszakadófélben lévő községekben. A törvény szerint (Zakon o lokalnoj samoupravi) azon községek kaphatnak városi rangot, amelyek gazdasági, adminisztratív, földrajzi és kulturális központjai egy adott régiónak és 100000 főnél több lakosuk van. A községi cím mind hatásköri, mind pedig pénzügyi szempontból hátrányosabb, mint ha városról lenne szó. A kutatómunka szempontjából az, hogy városról vagy községről beszélünk, a területi besorolást nem befolyásolja, csak a fejlettség szempontjából releváns.

A 2014-es besorolás alapján Vajdaság községei és városai az alábbi fejlettségi kategóriákba lettek besorolva.

- A köztársasági átlag feletti fejlettségűek: Szabadka, Újvidék, Magyarkanizsa, Zenta, Versec, Verbász Pancsova, Palánka, Pecsince, Ópázova, Belcsény.

- A köztársasági átlag 80-100\%-a közötti fejlettségűek: Apatin, Nagybecskerek, Ada, Topolya, Óbecse, Karlóca, Nagykikinda, Ruma, Zombor, Mitrovica, Temerin, Petrőc, Indija, Kula, Törökkanizsa. 
- A köztársasági átlag 60-80\%-a közötti fejlettségűek: Alibunár, Bács, Fehértemplom, Kishegyes, Törökbecse, Hódság, Szenttamás, Magyarcsernye, Zsablya, Ürög, Antalfalva, Kevevára, Szécsány, Titel, Csóka, Zichyfalva, Sid, Begaszentgyörgy.

- A köztársasági átlag 60\%-a alatt van a fejlettsége: Ópáva.

A fenti felsorolásban azon városokat (Szabadka, Versec, Pancsova, Nagybecskerek, Nagykikinda, Zombor) és községeket (Magyarkanizsa, Topolya, Temerin, Törökkanizsa) emeltem ki dőlt betűvel, amelyeket a későbbiekben részletesen vizsgálok.

E közigazgatási egységek fejlettségi szintjét 2010 és 2014 között vizsgáltam. Erre az időszakra álltak rendelkezésre adatok, illetve ekkor történt a fejlesztési projektek megvalósítása. Így bemutatható az, hogy milyen összefüggések vannak a projektek forrásainak lehívásában és sikeres megvalósításában, valamint a területi fejlődésben, ami véleményem szerint pozitív összefüggést kell, hogy mutasson: tehát azon községek, amelyek jelentős mértékben tudtak lehívni uniós forrásokat, fejlődési pályára álltak. Valamennyi mutatót csak azokban a községekben vettem figyelembe, amelyekben jelentős volt a lehívott projektek száma (legalább négy lezárt projekt a vizsgált periódusban). Újvidéket - mint tartományi székvárost és jóval nagyobb fejlettségü és lakosságszámú települést - nem vettem figyelembe a vizsgálat során, mert jelentősen torzította volna a mintát.

A fejlettségi besorolásokból (2. ábra) megállapítható, hogy a 2010 és 2014 közötti országos fejlettségi besorolás alapján nem mutatható ki szignifikáns fej-

2. ábra: Vajdasági községek fejlettsége a hivatalos besorolás alapján (2010-2014)

Development level of the municipalities/towns according to the official classification (2010-2014)

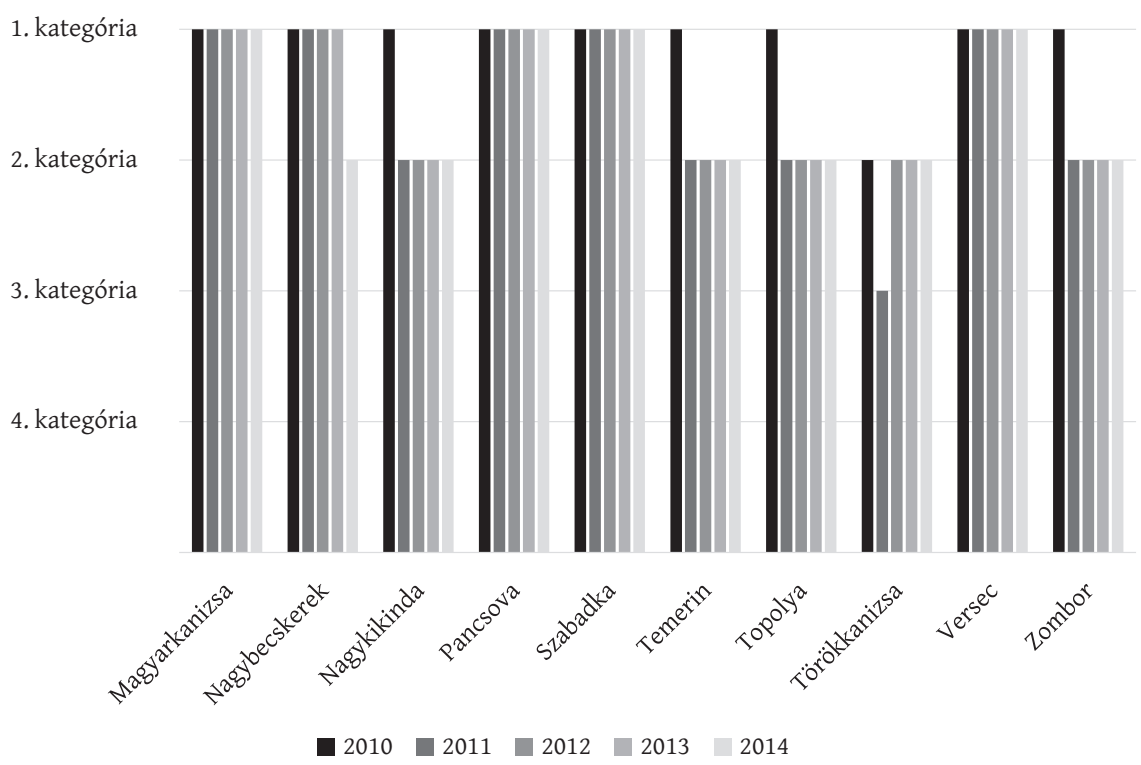


lődés, sőt alapvetően visszaesés mutatkozik egyes kisebb községek fejlettségében. A nagyvárosok (Pancsova, Szabadka, Versec) tartják legmagasabb fejlettségi szintjüket. Nagybecskerek (annak ellenére, hogy folyamatosan csökken a munkanélküliek száma) mégis a második legfejlettebb csoportba esett vissza 2014-re, ahogyan Zombor is egy kategóriát visszaesett. Magyarkanizsa az egyetlen olyan kisváros, amely folyamatosan tartja pozícióját a legfejlettebbek csoportjában (Republički Zavod za Statistiku 2011-2016a, 2011-2016b).

Összevetve a fejlettségi mutatót az uniós források abszorpciójával, kijelenthető, hogy nem látható összefüggés az egyes községek fejlettsége és a megvalósított projektek nagyságrendje között, mivel az esetek felében nemhogy nőtt volna, hanem inkább csökkent a fejlettségi mutató, valamint szintén az esetek felében eleve a legfejlettebb csoportba tartozott a vizsgált település. Egyedüli fejlődés Törökkanizsa esetében mutatható ki, amely 2011 után a harmadik kategóriából visszaküzdötte magát a másodikba. Ennek a nagyszámú nyertes projekt lehet az oka, mivel az adott periódusban az önkormányzati vezetők elmondása szerint nem volt más forrásból finanszírozott hasonló volumenű beruházás a község területén.

A kiválasztott városok és községek fejlettségi folyamatainak meghatározására az önkormányzati egységek költségvetéseinek bevételi és kiadási oldalát jellemző mutatókat használtam, amelyek jól szemléltetik, hogy milyen fejlettségű az adott település, mivel a bevétel nagy részét a helyi adók, a személyi jövedelemadó és a közintézmények (óvodák, iskolák, egészségügyi és szociális intézmények stb.) fenntartására átutalt köztársasági és tartományi transzferek képezik (Zakon o finansiranju lokalne samuprave). A kiadási oldal megmutatja, hogy az adott község megszorító vagy fejlesztési költségvetést tudott-e összeállítani egy-egy periódusra, ami alapján meg tudjuk állapítani fejlettségének szintjét, illetve időbeli változását. Mindkét mutató esetén jól definiálható trend mutatkozik: 2012-ig növekvő bevételek és kiadások, amely trend 2013-tól csökkenést mutat. Erőteljes ez a trendforduló a legmagasabb fejlettségi csoportba sorolt községek között, a fejletlenebb községek tartani tudták költségvetésük színvonalát vagy kismértékben növelték is azt, ami közvetlen kapcsolatban lehet az uniós források felhasználásával. Törökkanizsa, Temerin és Topolya, valamint 2012-ig Magyarkanizsa és Nagykikinda, illetve a városok - Szabadka, Pancsova és Nagybecskerek - gyors növekedését viszont nem lehet csak a projektek megvalósításának köszönni, hanem egyéb gazdasági és politikai folyamatok is szerepet játszottak ebben. A törés egyik oka valószínűen a kormány megszorító és centralizációs politikája, amely az önkormányzatok költségvetését és jogköreit is csökkenti.

Meglátásom szerint egy területegység fejlettségét jól mutatja az építőipari beruházások volumene. Erre a mutatóra szintén megfelelő adatsorok találhatók a Szerb Statisztikai Intézet publikációiban, így ezeket is használtam a fejlettségi szintnek és változásának a meghatározásához. Ez a mutató tartalmazza mindazon építőipari beruházásokat, amelyeket a magán- és a közszféra az adott év- 
ben végzett (gazdasági és lakóingatlanokat egyaránt). Hasonlóképpen meg tudjuk becsülni egy-egy térség fejlettségének változását, ha a gazdasági beruházásokat vizsgáljuk meg. Ez a mutató a felépített gazdasági célú objektumok és a termelésbe állított hazai, valamint külföldről beszerzett berendezések értékét jelenti. Az építőipari beruházások és az összes beruházás is hozzávetőlegesen hasonló volumenű a községekben, 2009 után csökkenés, majd 2011 után változó növekedés következik; talán csak a 2014-es évre mutatható ki valamelyes növekedés, ami a jövő szempontjából a gazdasági felzárkózást jelenthet. Az európai uniós források nem jelennek meg jelentős arányban a térség fejlesztésében, ezért a hazai és világgazdasági folyamatok elnyomják azok hatásait a beruházási mutatókban. Minimális az a keretösszeg, amely az infrastrukturális projektek támogatására fordítható, még ha a programok teljes költségvetésének felénél nagyobb összegről is beszélünk.

Ha a munkaerőpiacot vizsgáljuk, akkor két fejlettségi mutatót érdemes figyelembe venni: az állandó munkaviszonyban lévő alkalmazottak, illetve a munkanélküliek számát. Elméletileg a két mutatónak egymással szoros összefüggésben kellene állnia: ahogyan a munkaviszonyban lévők száma változik, a munkanélküliek számának is hasonló nagyságrenddel kellene változnia, de ellenkező előjellel. A vizsgált mintában viszont Nagybecskerek kivételével párhuzamos folyamat zajlott: 2010 után csökkent a foglalkoztatottak száma, és ezzel egyidejüleg csökkent a munkanélküliek száma is. Ennek az együttmozgásnak az okai a gazdasági válság, a nyitottabb határokat eredményező uniós csatlakozási folyamat, valamint a magyar kisebbség számára megadott kettős állampolgárság által gerjesztett kivándorlási hullám. Utóbbi 2014-re érte el a tetőfokát, ekkor a foglalkoztatási ráta mellett a munkanélküliség is jelentősen csökkent, főleg a nagyobb településeken (Pancsova, Szabadka, Nagybecskerek, Zombor, Nagykikinda).

Előbbi mutatóhoz szorosan kapcsolódik a nettó átlagkereset alakulása, amely 2013-ig szignifikánsan növekszik, majd megtorpan, hogy 2014-re némely esetben csökkenjen vagy csak jóval kisebb mértékben növekedjen.

A vizsgált mutatók alapján összességében megállapítható, hogy a Vajdaság határon átívelő uniós forrásokat legnagyobb mértékben lehívó településeinek fejlettsége a vizsgált időszakban jelentősen nem változott, csak minimális növekedés volt tapasztalható.

A projektabszorpciós készség (1. táblázat) és a fejlettség kombinálásával a vajdasági községeket/városokat 11 kategóriába lehet sorolni: a két véglet az átlag feletti fejlettségű város magas projektabszorpciós készséggel és a fejletlen település projektabszorpciós készség nélkül. Ezek térképi ábrázolása (3. ábra) szemlélteti, hogy földrajzilag hol vannak a jelentős támogatási csomópontok, melyek azok a térségek, amelyek folyamatosan leszakadóban vannak és az uniós források sem tudnak rajtuk segíteni. Továbbá az ábrán kirajzolódnak azok a helyek is, amelyek eredményesen ki tudták használni az elmúlt több mint 10 év határ menti programjaiban rejlő lehetőségeket, és azt a saját fejlődésük motorjává tudták tenni. 
1. táblázat: Egyes vajdasági községek projekt abszorpciós készsége

Project absorption capacity of certain municipalities in Vojvodina

\begin{tabular}{ll}
\hline Magas projektabszorpciós készség & $\begin{array}{l}\text { Magyarkanizsa, Törökkanizsa, Nagybecskerek, Ujjvidék, Pan- } \\
\text { csova, Szabadka, Topolya, Temerin, Versec, Nagykikinda, } \\
\text { Zombor }\end{array}$ \\
\hline Közepes projektabszorpciós készség & Ada, Fehértemplom, Kishegyes, Alibunár, Bács, Petröc, Csóka, \\
& Törökbecse, Zichyfalva \\
\hline Gyenge projektabszorpciós készég & Apatin, Palánka, Óbecse, Kúla, Magyarcsernye, Hódság, Ópáva, \\
& Ruma, Szenttamás, Verbász, Begaszentgyörgy \\
\hline Projektabszorpciós készség nélkül & $\begin{array}{l}\text { Belcsény, Inđija, Ürög, Antalfalva, Kevevára, Pecsince, Zenta, } \\
\text { Szécsány, Mitrovica, Karlóca, Ópazova, Sid, Titel, Zsablya }\end{array}$ \\
\hline
\end{tabular}

A 3. ábra megerősíti az előző részek következtetéseit: a jelentős fejlettséggel rendelkező községek és városok tovább növelték előnyüket a többi településhez képest, és e települések voltak képesek a legtöbb projektet is megvalósítani a határon átnyúló támogatások közül. A határ menti települések jelentős előnyre tettek szert a többi településhez viszonyítva. Ez főleg a magyar és a horvát programra vonatkozik, míg a román program projektjeit elsősorban a nagyvárosok kötötték le, ott a közvetlen határ menti, kevésbé fejlett községek

3. ábra: A vajdasági községek és városok fejlettségének és projektabszorpciós készségének viszonyrendszere

Relationship between the development level and the project absorption capacity of the municipalities and towns of Vojvodina

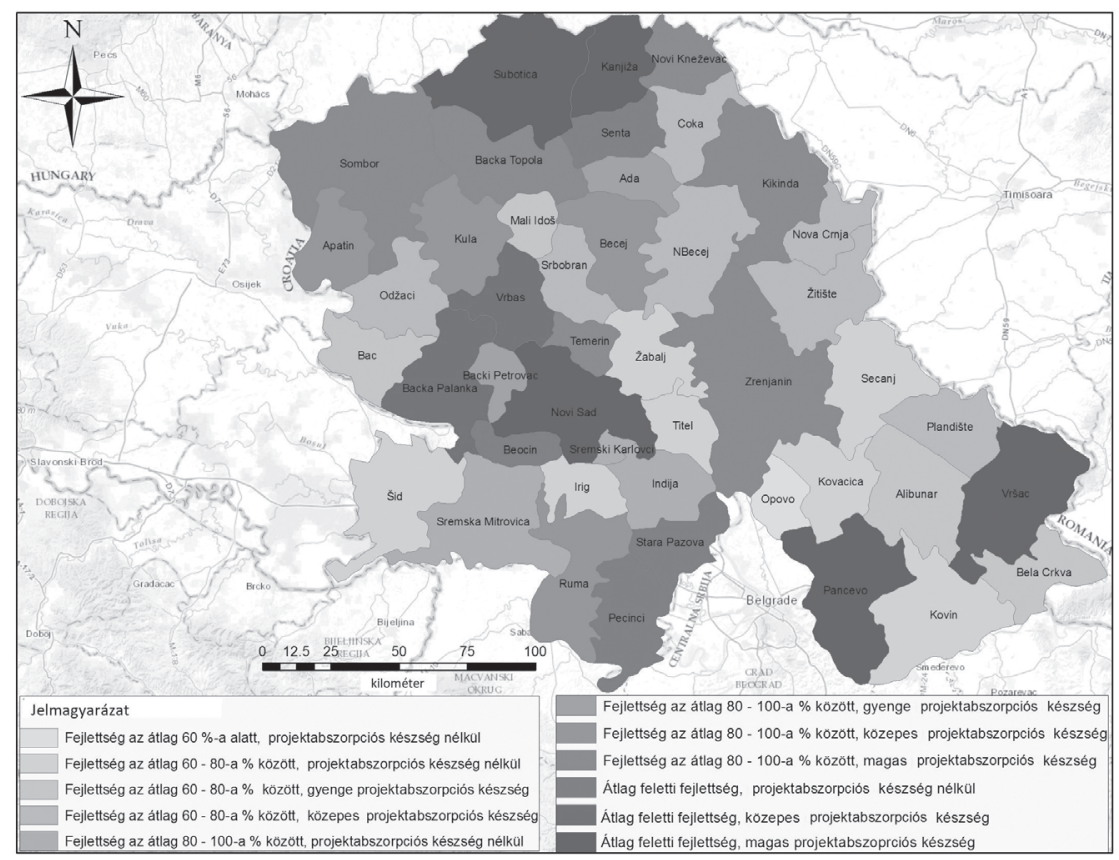


nem tudták kihasználni a programok által kínált esélyt. A Vajdaság észak-déli tengelyéhez kapcsolódóan jól kirajzolódik az összes határszakasztól távol eső, fejletlen községek által alkotott térség, amelynek gyenge projektabszorpciós készsége van vagy semennyi sincs, és ehhez hasonlóan a dél-bánáti, jellemzően alacsony fejlettségű települések sem tudtak jelentős forrásokat lehívni az uniós alapokból. Kivételt képeznek a jelentős projektabszorpciós kapacitással rendelkező nagyvárosok, Pancsova és Versec, amelyek vélhetően Belgrád közelségének is köszönhetően tudnak ilyen eredményt elérni.

\section{Összegzés}

A Vajdaság területén a legnagyobb mértékben a nagyvárosok, Újvidék és Szabadka, illetve az egyéb nagy- és középvárosok tudták lehívni az európai uniós határ menti támogatások nagyobb részét, mind relatív, mind abszolút számokban mérve, illetve ezeken a területeken valósultak meg nagyobb számban a projektek. Mivel a vizsgált programok alapvető célja a határon átívelő hatás erősítése és a periferikus térségek lemaradásának csökkentése volt, a határ közvetlen közelében lévő térségek magasabb arányban tudták lehívni a támogatási forrásokat, következésképpen azok hatásai is jelentősebbek voltak az adott területre (ami kimutatható mind az infrastrukturális outputindikátorokban, mind pedig az ezeken alapuló társadalmi mutatókban). Több határ menti község (Magyarkanizsa, Törökkanizsa, Szabadka, Zombor, Nagykikinda, Versec) is részt vett a projektek megvalósításában, jelentős mértékben hívva le forrásokat. Ha e községek fejlettségi mutatóit összevetjük a projekt előtti állapotokkal, akkor megállapítható, hogy kiugró fejlődés nem történt, így egyértelműen elvethető a bevezetésben tett feltételezés, miszerint a Vajdaság fejlődésének kulcskérdése az uniós források lehívásához füződik. A nagyobb városok fejlödési pályája 2012-ben megtörni látszik, a kisebbek (Magyarkanizsa és Törökkanizsa) viszont enyhe fejlődést mutatnak. A kisebb méretü települések számára tehát ezek a források fejlődési alternatívákat biztosítottak.

Összességében megállapítható, hogy az Európai Unió határon átnyúló programjai nem voltak pozitív hatással a Vajdaság területi fejlödésére. A 2007-2013 közötti időszak vizsgálata megmutatta, hogy a projektek nem tudták azokat a külső, elsősorban politikai és gazdasági hatásokat ellensúlyozni, amelyek meghatározták a terület fejlődési pályáját. A Vajdaság sohasem volt a szerbiai területfejlesztés fókuszában, periferiális térségként a közelmúltban Belgráddal szemben is elvesztette vezető szerepét. Az általam vizsgált három határon átívelő program sem adott kellő lendületet ahhoz, hogy egészséges és mérhető területi fejlődés bontakozzon ki. A megvalósított projektek megoldották egyes területek egyes problémáit, mint pl. határátkelők, határon átnyúló kerékpárutak, árvízvédelmi rendszerek építését, de ezek hosszú távú hatást nem eredményeztek, 
illetve ezek még nem mérhetők. A határ menti területek periferikus jellege viszont nem változott jelentősen, annak ellenére, hogy a határ menti programok célja a leszakadás csökkentése lenne.

Az eddig megvalósult fejlesztések nem csökkentették a hátrányos helyzetű régiók leszakadását, inkább növelték a különbségeket. Természetesen a támogatott projektek jelentős hatást gyakoroltak egy-egy mikroközösség életére - legyen az helyi vagy községi/városi -, kiváló alkalmat teremtettek a későbbi együttműködések kialakítására. Mindezek ellenére állítom, hogy a jövő egyértelműen az uniós finanszírozásban van, mivel az elmúlt évek során a hazai fejlesztési források sokszorosa került így a rendszerbe, és az előcsatlakozási alapok tervezett támogatásai az eddigi támogatások sokszorosai. Viszont a következő programozási időszakban jobban kellene ügyelni a területi és az ágazati arányok megtartására, a források területileg egyenlőbb elosztására.

\section{Jegyzet}

1 A szerb közigazgatási rendszerben a község egy nagyobb települést és az általa vonzott kisebb településeket jelenti, hasonlóan a magyarországi járási rendszerhez. A községnek vannak önkormányzati funkciói, az egyes településeknek csak korlátozott jogköreik vannak.

\section{Irodalom}

Baranyi B. (2001): A határ menti térség és a határon átnyúló kapcsolatok fejlődési esélyei. In: Baranyi B. (szerk): A határmentiség kérdőjelei az Északkelet-Alföldön. MTA RKK, Pécs, 338-368.

Baranyi B. (2014): Adalékok a határmentiség újraértelmezéséhez Magyarországon. Deturope. 2., 26-45. Böröcz J. (2002): A határ: társadalmi tény. Replika, 47-48., 133-142.

Fertő I., Varga Á. (2015), Az európai uniós támogatások hatása a kistérségek helyzetére. Tér és Társadalom, 1., 116-131. http://doi.org/ckhh

Hardi T. (2010): Térségeink és városaink határon átnyúló kapcsolatrendszerének átalakulása a közelmúltban. In: Barta Gy., Beluszky P., Földi Zs., Kovács K. (szerk.): A területi kutatások csomópontjai. MTA Regionális Kutatások Központja, Pécs, 291-304.

Hardi T., Hajdú Z., Mezei I. (2009): Határok és városok a Kárpát-medencében. MTA RKK, Győr, Pécs

Horváth Gy. (2015): A kelet-közép-európai területfejlesztés megújításáról. In: Takács Z., Ricz A. (szerk.): Regionális kaleidoszkóp. Regionális Tudományi Társaság, Szabadka. 53-62.

Horváth Gy., Hajdú Z. (2010): Regionális átalakulási folyamatok a Nyugat-Balkán országaiban. MTA RKK, Pécs, 9-24.

Instrument pretpristupne pomoći (IPA) Prekogranični program Hrvatska-Srbija 2007-2013. Programski Dokument, 2008.

Kovács A. D. (2012): Területfejlesztési kihívások a szerb-magyar határtérségben. In: Nyári D. (szerk.): Kockázat-Konfliktus-Kihívás. A VI. Magyar Földrajzi Konferencia, a MERIEXWA nyitókonferencia és a Geográfus Doktoranduszok Országos Konferenciájának Tanulmánykötete. Szegedi Egyetem, Természeti Földrajzi és Geoinformatikai Tanszék, Szeged, 417-428. 
Kuttor D., Ocskay Gy. (2015): A határok változó szerepe, határ menti kapcsolatok. In: Fábián A. (szerk.): Otthon a Kárpát-medencében. Területfejlesztési Szabadegyetem 2011-2015. Nyugat-magyarországi Egyetem Kiadó, Sopron. 485-512.

Lazarević, G., Knežević, I., Božić, R. (2011): Prekogranična saradnja. Evropski pokret u Srbiji. Beograd

Nađ, I., Ric, A., Ribar, Đ., Nađ, M., (2015): Spremnost i pripremljenost lokalnih samouprava AP Vojvodine za prijem is korišćenje razvojnih fondova Evropske Unije. Prospero, Temerin, 30-43.

Nezavisno Društvo Novinara Vojvodine (2015): Evropa u Vojvodini. Pregled $i$ analiza realizovanih projekata lokalnih samouprava na teritoriji AP Vojvodine finansiranih od strane EU u programskom periodu 2007-2013. Novi Sad

Pejović, A., Lazović, M., Mirić, O., Knežević, I. (2014): IPA II. Instrument za pretpristupnu pomoć EU 2014-2020. Friedrich Ebert Stiftung, Evropski pokret u Srbiji, Beograd

Petak, Z. (2005): Ekonomska pozadina raspada socijalističke Jugoslavije. In: Fleck, H., Graovac I. (szerk.): Dijalog povjesničara-istoričara. Friedrich Naumann Stiftung, Zagreb. 58-77.

Pete M. (2014): Investitgating the Role of Borders in the Transformation of Space in the Light of the European Union's Regional Policy. In: Cross-Border Review Yearbook 2014. Central Eurpean Service for Cross-Border Initiatives, Budapest. 21-36.

Prime Minister's Office (2015): Hungary-Serbia IPA Cross Border Co-operation Programme, Project Catalog. Budapest

Program razvoja Ap Vojvodine 2014-2020. Vlada Ap Vojvodine, Novi Sad, 2013.

Rechnitzer J. (1999): Határ menti együttmüködések Európában és Magyarországon. In: Nárai M., Rechnitzer J., (szerk.): Elválaszt és összeköt - a határ, Társadalmi-gazdasági változások az osztrák-magyar határ menti társégben. MTA RKK, Pécs, Győr. 9-72.

Republički Zavod za Statistiku (2011-2015): Opštine i regioni u republici Srbiji 2011-2015. Beograd

Republički Zavod za Statistiku (2011-2016a): Statistički godišnjak 2011-2016. Beograd

Republički Zavod za Statistiku (2011-2016b): Statistički kalendar Srbije 2011-2016. Beograd

Ricz A. (2012): A határon átívelő programok hatásai Vajdaság területi fejlődésére - az ezeken alapuló területi együttműködések továbbfejlesztésének lehetőségei. Észak-magyarországi Stratégiai Füzetek, 1., 90-103.

Ricz A. (2015): Vajdasági magyar civil szervezetek és az európai uniós programok. In: Bodó B. (szerk.): Erdélyi Magyar Civil Évkönyv. Magyar Civil Szervezetek Erdélyi Szövetsége, Kolozsvár, 125-136.

Ricz A. (2016): A határon átívelő európai uniós finanszírozású programok hatásai és területi dimenziói Vajdaságban. In: Gábrity Molnár I. (szerk.): Kutatások sodrásában. Magyarságkutató Tudományos Társaság, Szabadka, 167-180.

Romania-Serbia IPA Cross-Border Cooperation Programme Programming Document, 2008.

Strategija regionalnog razvoja republike Srbije za period od 2007 do 2012 godine. A Szerb Köztársaság Hivatalos Közlönye 21/2007.

Szabó Gy. (2005): A határ menti együttműködést elősegítő és akadályozó tényezők empirikus vizsgálatok tükrében. Baranyi B. (szerk.): Közelitések. A határon átnyúló kapcsolatok kilátásai és a mezőgazdasági regionális kérdései az Európai Unió keleti peremén. MTA RKK, Debrecen, 86-96.

Tripković, M. (2003): Regionalizálódás Szerbiában, különös tekintettel a Vajdaság helyzetére Tér és Társadalom, 4., 117-155.

Uredba o nomenklaturi statistickih teritorijalnih jedinica. A Szerb Köztársaság Hivatalos Közlönye, 109/2009, 46/2010.

Uredba o utvrdjivanju metodologije za izračunavanje stepena razvijenosti regiona i jedinica lokalne samouprave. A Szerb Köztársaság Hivatalos Közlönye, 68/2011.

Zakon o lokalnoj samoupravi. A Szerb Köztársaság Hivatalos Közlönye, 129/2007, 83/2014.

Zakon o finansiranju lokalne samuprave. A Szerb Köztársaság Hivatalos Közlönye, 95/2015. 